\title{
THE MEANING OF STRUCTURE AND THE MINIMALIST PROGRAM
}

Hans Bennis, Holland Institute of Generative Grammar, Leiden University, PO Box 9515, 2300 RA Leiden, the Netherlands.

In the minimalist framework (Chomsky 1993) the presence of functional structure and the application of movement operations are determined by lexical and morphological features. In this paper it is argued that both functional structure and movement operations make substantial contributions to the interpretation of lexical elements and syntactic constructions. It will be argued that the Dutch lexical element wat is an open quantifier without inherent lexical meaning. It derives its interpretation from its configurational properties. The fact that wat can be interpreted as either indefinite ( $\mathrm{k}$ heb wat gesien 'I have seen something'), interrogative (Wat heeft hij gezien? 'What did he see?') or exclamative (Wat ging hij tekeer! 'He went completely crazy!') does not follow from ambiguity of the lexical item wat, but from the position of wat in the configuration. In this sense we may consider wat to constitute a perfect example of the 'meaning of structure'. The relevance of this issue for linguistic theory is that we have to adopt a model in which interpretation is an integrative part of the syntactic module of the grammar.

Binne die minimalistiese raamwerk (Chomsky 1993) word die teenwoordigheid van funksionele struktuur en die toepassing van skuifreels bepaal deur leksikale en morfologiese kenmerke. In hierdie artikel word aangevoer dat sowel funksionele struktuur as skuifreels beduidende bydraes maak tot die interpretasie van leksikale elemente en sintaktiese konstruksies. Daar sal beweer word dat die Nederlandse leksikale element wat ' $n$ oop kwantifiseerder is, sonder inherente leksikale betekenis. Die interpretasie daarvan word afgelei uit sy konfigurasieeienskappe. Die feit dat wat geinterpreteer kan word, of as onbepaald (Ik heb wat gezien 'Ek het iets gesien'), of as interrogatief (Wat heeft hij gezien? 'Wat het hy gesien?), of as uitroep (Wat ging hij tekeer! 'Hy het mal geword!'), is nie die gevolg van die meerduidigheid van die leksikale item wat nie, maar wel van die posisie van wat in die konfigurasie. In hierdie opsig kan wat beskou word as 'n perfekte voorbeeld van die 'betekenis van struktuur'. Die relevansie van hierdie kwessie vir die taalteorie lê daarin dat' $n$ model aanvaar moet word waarin interpretasie ' $n$ integrerende deel van die sintaktiese module van die grammatika vorm. 


\section{INTRODUCTION}

In the minimalist framework (Chomsky 1993) the presence of functional structure and the application of movement operations are determined by lexical and morphological features. ${ }^{1}$ Due to the adoption of the strong version of the lexicalist hypothesis Chomsky assumes that fully inflected lexical elements are inserted into the syntactic structure. Movement of a particular head or constituent is caused by the fact that the head/ constituent contains a feature that has to be checked in order to create a well-formed representation at the level of LF. So, if a constituent has a morphological or lexical feature $[+F]$, the constituent has to be moved to a $[+F]$ functional projection in order to create a configuration in which the features $[+F]$ can be checked. Depending on the strength of a particular feature in a particular language the movement takes place before or after Spell-Out. It is of course evident that this system causes a particular feature to be represented twice in the underlying structure. This is demonstrated in (1) for features such as [+agr] and [+wh].

$$
\text { a } \quad \text { b... AGR }[+ \text { agr }] \ldots . . .
$$$$
\text { NP [+agr] }
$$$$
\text { NP }[+w h]
$$

At LF the NP has to be moved to the specifier of AgrP resp. CP in order to create a configuration in which the feature $[+\mathrm{agr}] /[+$ wh] is checked. This movement is visible, i.e. before Spell-Out, if the feature is strong, or not visible, i.e. after Spell-Out or at LF, if the feature is weak. In this way variation between languages can be made dependent on the strength of these features. For instance, the difference between a VO-language such as English, and an OV-language as Dutch might be due to the strength of the feature [+agr], causing the object to move across $\mathrm{V}$ before Spell-Out in an OV-language, and at LF in a VO-language. Similarly, the difference between languages with overt Wh-movement (English, Dutch) and languages without overt Wh-movement (Chinese) can be related to the strength of the feature $[+w h]$ in (1b).

However, a disadvantage of this theory is that it forces us to represent features of the type $[+w h]$ in the underlying structure twice. The moved element and the landing site have to be marked for [+wh] in order for the movement to take place. More general it follows that for each morphological or lexical feature of lexical items there has to be a corresponding functional projection. If this were not the case the feature of the lexical item cannot be checked, which would give rise to an unwellformed LF-representation. It is not immediately obvious that a double feature representation leads to redundancy within the theory. In previous proposals it was generally accepted that a wh-word (lexical 
Meaning of structure and the minimalist program

feature) is moved to the Wh-operator (functional feature) as well. However, there are other cases in which the redundancy becomes more manifest. Take for instance the phenomenon of Scrambling in Dutch, as exemplified in (2).

(2) a dat Jan gisteren twee boeken kocht
that John yesterday two books bought
b dat Jan twee boeken gisteren kocht

If we assume that (2a) represents the underlying order (cf. Bennis \& Hoekstra 1984 ), and that (2b) is derived by movement of the object across the adverbial, there has to be a feature in (2b) that forces this movement to take place. If we compare the interpretation of (2a) and (2b) we notice that these sentences differ in such a way that twee boeken can be interpreted as indefinite and as specific in (2a), but as specific only in (2b). To account for this it has been proposed (Diesing 1988) that the existential operator is located at the left edge of VP. If the NP is moved out of VP by Scrambling, it is moved out of the domain of the existential operator, and it can no longer receive an existential interpretation. By consequence it has to be interpreted as specific. In this view the movement of an NP has interpretive consequences. However, no such analysis is available in the minimalist framework. Given the feature approach described above, we probably have to assume that an NP such as twee boeken must have a feature [+indef] or [+specific]. Moreover, the structure has to contain the functional projections IndefP and SpecP. The feature [+indef] must be weak to account for the absence of an indefinite interpretation in (2b), while the feature [+specific] might be strong or weak, giving rise to (2b) and (2a) respectively. It is evident that this results in a rather clumsy and redundant account of the sentences in (2). An approach in which the configuration contributes to the interpretation is strongly preferred.

In this paper I argue that the occurrence of the Dutch pronoun wat can receive an optimal explanation only if we assume that it is not lexically specified as, for instance, [+wh]. It will be shown that it is the position of wat in the configuration that determines its interpretation. This is in conflict with the morphological approach of the minimalist framework. In future work I hope to show that we can retain much of the basic assumptions of the minimalist program if we replace the morphologically driven system by an interpretively driven system.

The main empirical issue in this paper is the internal structure of the Dutch wat voor-construction. This construction has been the subject of much debate in the past fifteen years (cf. Reuland 1983, Bennis 1983, Den Besten 1985 and Corver 1990). In all these analyses wat voor (een) was taken to be some kind of idiomatic specifier, comparable to the normal Wh-specifier welke ('which'). I will argue that the structure of the wat voor-construction is not 
idiomatic at all. ${ }^{2}$ In order to show this, I have to discuss the apparently irregular use of the three constituent elements: wat, voor, and een. Wat ('what') does not behave as a question pronoun, voor ('for') is not a preposition, and een ('a') is not an indefinite determiner. One of the important assets of this discussion is that it provides us with a straightforward explanation of the fact that wat can be extracted from NP.

\section{WAT AS A CONSTITUENT}

In Postma (1994, 1995) it is argued that the interpretation of wat is configurationally determined. Wat is interpreted as a question pronoun if it is moved to [SPEC,CP], and as an indefinite pronoun if it remains within VP. Examples are given in (3).

(3) a Wat heb jij gezegd?

What did you say?

*Something did you say

b Ik heb wat gezegd

I have something said

*I have what said?

Postma shows quite convincingly that the difference in interpretation is not due to a lexical difference involving two different lexical items wat. There is only one lexical element wat, the interpretation of which depends on the syntactic position in the configuration. If it is moved to the Wh-operator position in [SPEC,CP] wat is interpreted as an interrogative word; if wat is in the scope of the existential operator, which is located at the left edge of VP (cf. Diesing 1988), it receives a strictly indefinite, non-specific interpretation. ${ }^{3}$ There is a third quantificational interpretation of wat. Wat can also be used as an exclamative marker, as in (4).
(4) a Wat is hij mij tegengevallen!
What is he me disappointed
b Wat ging hij tekeer!
What went he crazy

In the sentences in (4) wat can only be interpreted as an element that marks the exclamative function of the sentence. Although interrogative wat occupies the same position as exclamative wat, no ambiguity arises. Interrogative wat has to bind a variable in an argument position, whereas exclamative wat can only be related to non-argument positions. This is shown in (5). In (6) it is demonstrated that indefinite wat may appear either as an argument or as an adjunct. 
(5) a *Wat is hij jou tegengevallen?

What is he you disappointed?

b *Wat heeft hij gezegd!

What has he said!

(6) a Hij heeft wat gekocht

He has something bought

b Hij is mij wat tegengevallen

$\mathrm{He}$ is me somewhat disappointed

'He has disappointed me slightly'

Extending Postma's hypothesis, we may formulate the following generalization:

The interpretation of wat is not determined by lexical properties, but is derived structurally:

- If the Q domain is CP: WH or EXCL

If $w$ at binds an A position: WH

If wat does not bind an A position: EXCL

- If the $\mathrm{Q}$ domain is VP (A or $\left.\mathrm{A}^{\prime}\right)$ : INDEF

The next question is what properties of wat cause this lexical element to behave like this. The only property that the three interpretations of wat have in common is that wat is a quantificational element. I will take this to be the only lexical property of wat, as is formulated in the hypothesis in (8).

Hypothesis:

Wat is a quantifier without meaning

If (8) is correct, it follows that wat has no inherent $\phi$-features. Traditionally wat is taken to be a third person, neuter pronoun. If we compare wat with its non-neuter counterpart wie ('who'), we observe that wie, apart from having no exclamative or indefinite interpretation, differs from wat in that wie may show singular or plural agreement, depending on the context, whereas wat only has singular agreement, as is shown in (9).

(9) a Wat staat / *staan daar op de tafel?

What stands / stand there on the table

b Wie staat / staan daar op de tafel?

Who stands / stand there on the table

If wie is interpreted as plural, it triggers plural agreement. Although wat may also be interpreted as plural, it nevertheless must have singular agreement. The fact that singular agreement shows up in (9a) is not an accident. Singular is the unmarked value, as is evident from finite subjectless sentences, as in (10).

(10) a In het stadion wordt / *worden gevoetbald

In the stadium is / are played football

b Telkens blijkt / *blijken dat zij gelijk hebben

Everytime appears / appear that they right have 
If we take the unmarked value of a feature to be the absence of a feature we are able to explain the facts in (9). Given (8), wat has no feature for number, it thus cannot trigger plural agreement. Since a Spec-Head relation requires feature-identity of the Specifier and the Head, the absence of features on the specifier (the subject) leads to the absence of features on the head (the finite verb), thus causing the verb to show up as 'singular'. In a similar fashion I will take 'third person' to be the absence of a person feature. That nonpronominal NPs do not show agreement for first and second person (although they may refer to first or second person, eg. in epithets) might be taken as a consequence of the absence of person features on non-pronominal NPs.

The $\phi$-feature gender can also be shown to have neuter as the unmarked value, or rather, neuter is the absence of the gender feature. This is clear from adjectival agreement. In indefinite NPs only the combination of singular and neuter leads to the absence of the adjectival agreement suffix $-e$. This is demonstrated in (11).

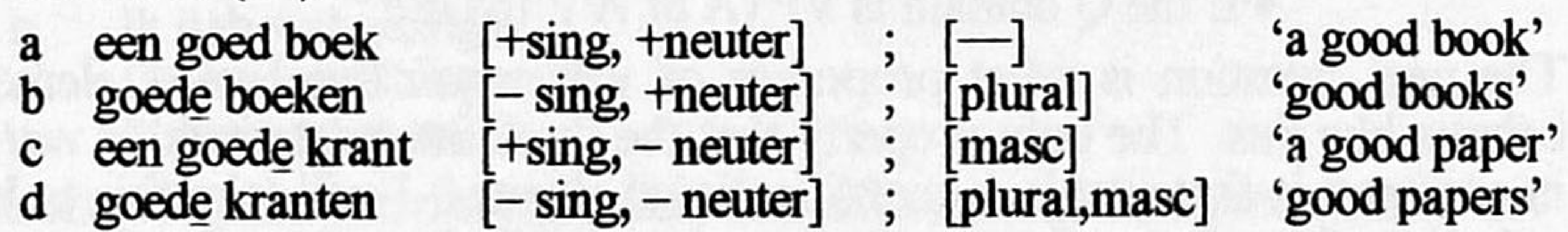

In this analysis the absence of morphological agreement in (11a) indicates the absence of agreement, and thus the absence of features, as is indicated after the semicolon in (11). This view is corroborated by the fact that wat appears as a relative pronoun only if the antecedent has no features (i.e. neuter, singular):

(12) a alles/elk boek [-] wat ik heb gelezen everything/each book what I have read

b *elke krant [masc] wat ik heb gelezen each newspaper what I have read

c *alle boeken [plural] wat ik heb gelezen

d *alle kranten [masc, plural] wat ik heb gelezen

I thus conclude that wat is a quantifier without meaning. The interpretation is completely determined by the configuration.

\section{WAT AS PART OF AN NP}

Interestingly, wat within NP may also trigger the same three interpretations: indefinite, exclamative and interrogative. This is shown in (13).
[Wat voor een boeken] leest hij?
Interpretation: WH
What for a books read hij
b [Wat een boeken] leest hij!
Interpretation: EXCL
What a books reads he 
c Hij leest [wat boeken]

He reads what books

Interpretation: INDEF

As is shown in (14)-(16), the internal structure of the whole noun phrase determines the interpretation of wat. The position of the NP or the A vs $\mathrm{A}^{\prime}$ relatedness does not appear to change the interpretation.

(14) a *[Wat voor een boeken] leest hij!

b *Hij leest [wat voor een boeken]

(15) a *[Wat een boeken] leest hij?

b *Hij leest [wat een boeken]

(16) a *[Wat boeken] leest hij?

b *[Wat boeken] leest hij!

Interpretation: EXCL

Interpretation: INDEF

Interpretation: WH

Interpretation: INDEF

Interpretation: WH

Interpretation: EXCL

Externally the NP behaves just like a regular interrogative, exclamative or indefinite NP. The difference between wat-constituents and [wat ...]constituents is illustrated below.

(17) a *Wat koopt hij!

b [Wat een boeken] koopt hij!

What (a books) buys he

(18) a *Wat werkt hij?

b [Wat voor uren] werkt hij?

What (for hours) works he

(19) a *Wat ligt er op de grond (indef.interpr.)

b [Wat zand] ligt er op de grond (indef.interpr.)

What (sand) lies there on the ground

(20) a *Ik heb wat gisteren aan Jan verkocht

b Ik heb [wat boeken] gisteren aan Jan verkocht

I have what (books) yesterday to John sold

(17) shows that exclamative [wat ...] may bind a variable in an A-position, but exclamative wat may not. (18) shows that interrogative wat cannot be an adjunct, but interrogative [wat ...] can. From (19)-(20) it follows that the condition that indefinite wat must remain within VP and cannot be moved by Wh-movement or Scrambling does not hold for indefinite [wat ...]. ${ }^{5}$

I conclude that the interpretation of wat in NP is determined NP-internally. The [wat ...]-NP behaves like an ordinary quantified NP. The following three types of [wat ...] can be found:

(21) [wat ...]-NP-types:

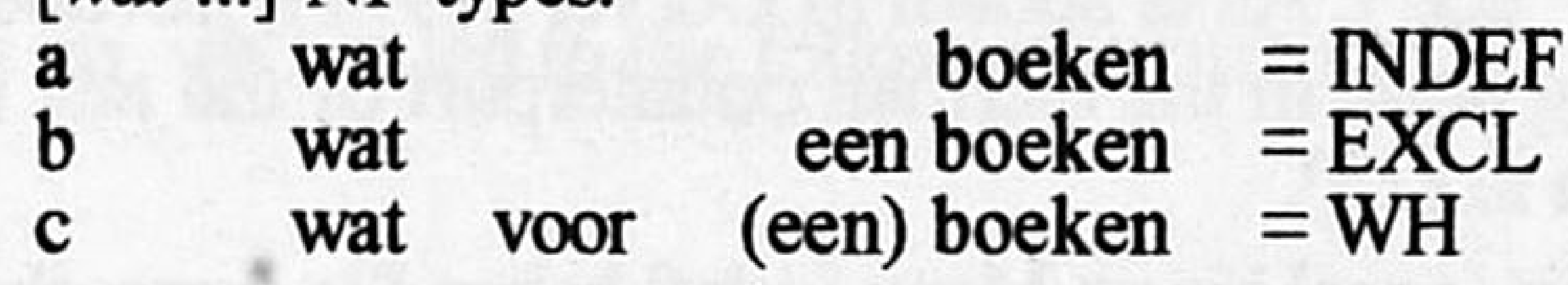




\section{VOOR AS A WH-COMPLEMENTIZER IN NP}

Although it might be claimed that the interpretation of the NPs in (21) is determined by the interpretation of the idiomatic specifiers wat, wat een and wat voor (een), it would seriously undermine our hypothesis that wat is just a bare quantifier. Moreover, it would not provide us with any perspective on an explanation of the similarities between the NPs in (21). One of these similarities is the fact that there is no agreement between the specifier and the noun. Although wat is generally taken to be singular and neuter (see above), the noun in the constructions in (21) can be singular or plural, neuter or nonneuter, as is shown in (22).

(22) a wat lucht [masc,sing] / jongens [masc,plu] / zand [neuter, sing]? what air / boys / sand

b wat een jongen / jongens / boek! what a boy / boys / book

c wat voor jongen / jongens / boek? what for boy / boys / book

Finally, it would be a virtual coincidence that wat is used in these three [wat ...]-constructions, and that the same three different interpretations can be observed if wat appears as a single constituent. The remarkable similarities between the NPs in (22) and between wat and [wat ...] constitute sufficient ground to leave the rather stipulative standard analysis, and to look for an alternative. One major ingredient of this analysis should be the fact that wat appears as a quantifier without meaning, as formulated in the hypothesis in (8). If that hypothesis is correct, the Wh-interpretation of (21c) cannot be due to the presence of wat. Given the paradigm in (21) the only available candidate for determining the Wh-interpretation of (21c) is the prepositional element voor. Although I have not been able to find direct, independent evidence for the claim that voor determines the interrogative interpretation of the $[$ wat voor ...]-NP, there are several indirect arguments that provide circumstantial evidence.

First of all, it is quite clear that voor does not have the properties that we would expect it to have if voor is used as a preposition. With respect to Case, categorial status, and interpretation there is hardly any resemblance with the preposition voor ('before' / 'for'). As is shown in Corver (1991), für does not assign Case to the following noun in the German counterpart of the wat voorconstruction. This is shown in (23).

(23) a Mit [+dat] was fur [+acc] einem Mann [+dat] haben Sie gesprochen?

b *Mit[+dat] was fir [+acc] einen Mann [+acc] haben Sie gesprochen?

With what for a man have you spoken

'With what kind of man did you speak' 
The Case of the phrase following voor/für is determined by the position of the whole [wat voor ...] phrase. In (23) it is the preposition mit that determines the Case of the phrase einem Mann.

Similarly, the embedded noun determines agreement in subject-verb agreement contexts, as is evident from (24).

(24) a Wat voor (een) jongen loopt / *lopen daar?

What for (a) boy walks / walk there

b Wat voor (een) jongens *loopt / lopen daar?

If voor was a preposition, we would expect the phrase following $\mathrm{P}$ to be the object of P. In that case the construction in (24) would be similar to the construction in (25).

Welke van de jongens loopt / lopen daar?

Which of the boys walks / walk there

In (25) van de jongens is a partitive PP. Agreement is determined by welke, which can be either singular or plural, depending on the interpretation. We have seen above that wat triggers no agreement, thereby forcing the finite verb to appear as singular (cf. 9a). The only way to account for the agreement facts in (24) is to assume that the noun following voor determines the number of the NP. This implies that voor (een) jongen $(s)$ in (24) is not a PP. ${ }^{6}$

Another argument to show that interrogative wat is not the head of this construction comes from the contrast between interrogative wat and [wat voor ... ] with respect to the possibility to appear as a relative pronoun:

(26) a alles wat $i k t_{i}$ heb gelezen everything what I have read

b *alles wat ik [ $t_{i}$ voor boeken] heb gelezen everything what I for a books have read

c *alles [wat voor boeken] $]_{i} i_{k} t_{i}$ heb gelezen

From (26b-c) it follows that the interpretation of the wat voor-construction is restricted to interrogative contexts. ${ }^{7}$ This cannot be due to wat, as is shown in (26a). Something else has to mark the wat voor-construction as interrogative.

The discussion so far leads us to the conclusion that wat is not the head of the wat voor phrase. Moreover, we have established that wat behaves like a bare quantifier, and that voor does not behave like a preposition. If we add these things up, we are led to the following structure: 


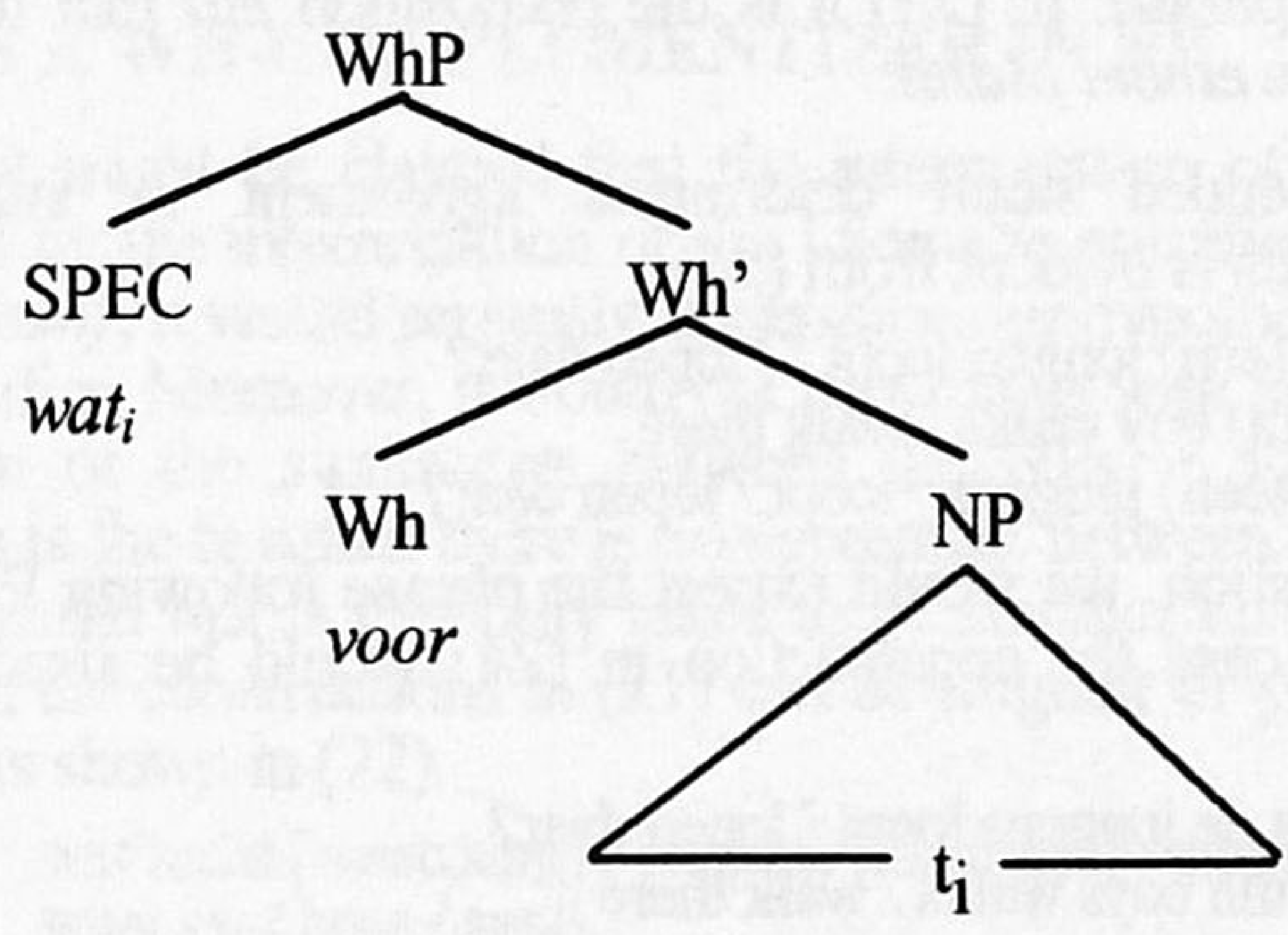

In (27) voor determines the interrogative status of the whole phrase, and wat behaves like a quantifier that is moved to the operator position in [SPEC,WhP]. In this structure voor is a functional head in the nominal domain. It occupies a position similar to the complementizer position in (interrogative) clauses. Interestingly, voor may also appear as a complementizer introducing finite or infinitival clauses. This is shown in (28).

(28) a Dit is een boek om/\%voor/*e op tafel te leggen

This is a book for on table to put

b Jan ging weg voor (voordat)/*na (nadat)/*om (omdat) ik binnenkwam John left before/after/because I entered

Although it gives rise to a somewhat marked and substandard result, the standard complementizer om can be replaced by voor in infinitival relatives, as in (28a).

Of the complementizers consisting of a preposition followed by the finite complementizer dat ('that'), voordat, doordat, nadat, omdat, opdat, only voor allows deletion of dat. Given the fact that the complementizer position cannot be empty in finite clauses, (28b) indicates that voor may appear as a complementizer as well (cf. Bennis \& Hoekstra 1984).

One of the major advantages of the structure in (27) is that it allows us to explain wat-extraction from NP in precisely the same way as Wh-extraction from CP. The well-known ECP-type effects of wat-extraction from subjects or adjuncts (cf. Den Besten 1985) are parallel to the ECP-effects in extraction from subject- or adjunct CPs. Wat-extraction from an NP in object position is fully acceptable (29a), whereas the acceptability decreases if wat is extracted from an NP in subject position (30a) or adjunct position (31a). 
(29) a Wat ${ }_{i}$ heeft Jan [ $t_{i}$ voor boeken] gelezen?

What has John for books read

(30) a ??Wat hebben [ $t_{i}$ voor jongens] dit boek gelezen?

What have for boys this book read

b Wat voor jongens hebben dit boek gelezen?

(31) a ??Wat ${ }_{i}$ heeft Jan [ $\mathrm{t}_{\mathrm{i}}$ voor periode] aan dat boek gewerkt?

What has John for period on that book worked

b Wat voor periode heeft Jan aan dat boek gewerkt?

From the discussion in this paragraph we may conclude that voor appears as a functional head with an interrogative interpretation in the [wat voor ...] construction. Wat is a bare quantifier that occupies an operator/A'-position entirely similar to the position of the Wh-phrase in [SPEC,CP]. Whextraction from NP is thus structurally similar to Wh-extraction from CP.

\section{THE FUNCTION OF EEN}

The third 'idiomatic' element in the [wat voor (een) ... ] construction is een (' $a$ '). This lexical element normally appears as the indefinite, singular determiner of noun phrases. However, in this construction it must have a different function. It shows up in front of plural and non-count nouns, in which the indefinite determiner een is not allowed.
a
wat voor (een) jongen/boek?
what for a boy/book
b wat voor (een) jongens/boeken? what for a boys/books
c wat voor (een) zand/vrijheid? what for a sand/freedom

a' een jongen/boek

a boy/book

b' *een jongens/boeken

a boys/books

c' *een zand/vrijheid

a sand/freedom

The questions that need to be asked with respect to een in the wat voor (een) construction are: Why is een allowed in this construction, and, why does it appear?

In order to answer these questions, we will have a look at the exclamative [wat een ...] construction, discussed in paragraph 2, first. Just as in (32), een in the exclamative construction doesn't seem to have $\phi$-features: een appears in this construction irrespective of the number or the countability of the following noun. If we leave out voor, the NPs in (32a-c) turn into acceptable exclamative NPs, as is shown in (33).
(33) a
[Wat *(een) jongen/boek] is dat!
What a boy/book is that
b [Wat *(een) jongens/boeken] zijn dat!
What a boys/books are that
c [Wat *(een) zand/vrijheid] is dat!
What a sand/freedom is that 
A difference between (32) and (33) is that the presence of een is obligatory in the exclamative [wat een ...] construction, and optional in the [wat voor (een) ...] construction. It might be tempting to argue that the exclamative interpretation in (33) is caused by the occurrence of 'exclamative een'. The hypothesis in (8) forces us to adopt the view that exclamation does not depend on a lexical property of wat. The view that the exclamative interpretation is not a consequence of lexical properties of wat in the [wat een ...] construction is corroborated by the fact that the exclamative construction shows up without wat, as is shown in (34).
(34) a Deze jongen koopt me toch (een) boeken!
That boy buys me still a books
b (Een) boeken dat deze jongen koopt!
A books that this boy buys

However, the facts in (34) also indicate that the exclamative interpretation cannot be due to een. A striking difference between (33) and (34) is that een is obligatorily present in the wat-exclamative construction in (33), while the presence of een is optional in the exclamative sentences in (34). Apparently the exclamative interpretation is not due to a particular lexical element. How do we account for the fact that wat-exclamatives require een to be present? We formulate the following questions:

- Why does featureless een appear in these constructions?

- Why is een optional in the wat voor construction and the wat-less exclamative construction?

- Why is een obligatory in the wat-exclamative construction?

These questions are extensively addressed in Bennis, Corver \& Den Dikken (1995). I will present a very short summary of that analysis here. The basic idea is that wat in the [wat ...] constructions starts out as the predicate of a Small Clause, as in (35).

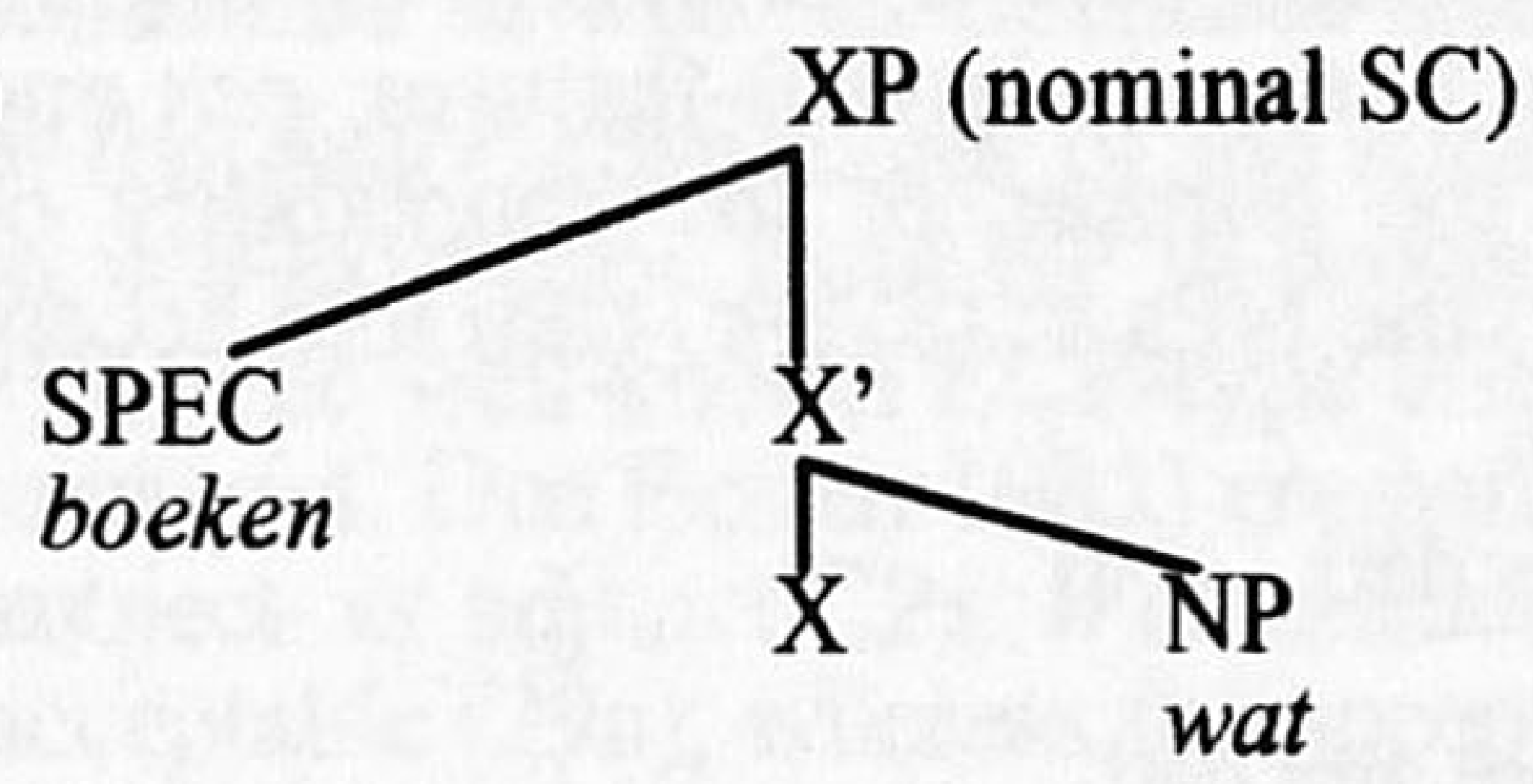

Given that wat is a quantifier, wat has to be moved to an operator phrase. In the constructions under discussion there are two relevant operator phrases, for reasons of convenience labelled as $\mathrm{WhP}$ and ExclP in (36). 
(36) a

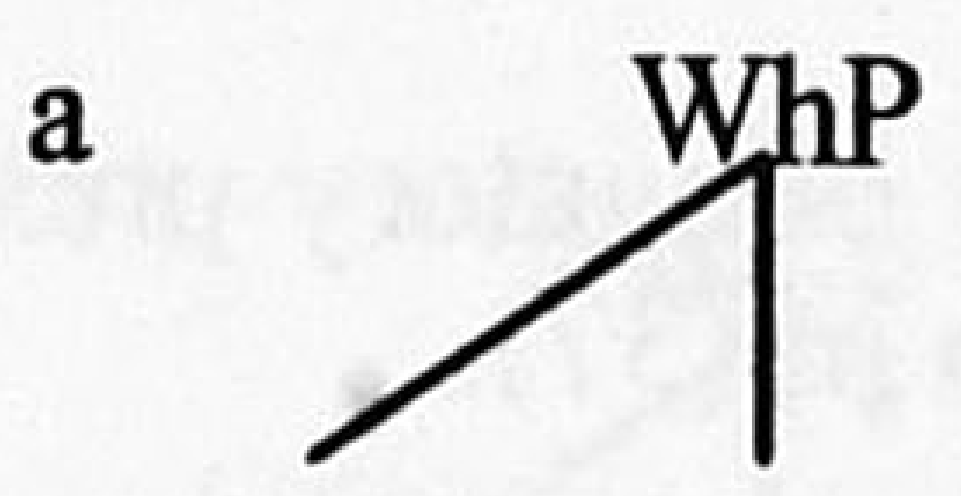

SPEC Wh' b

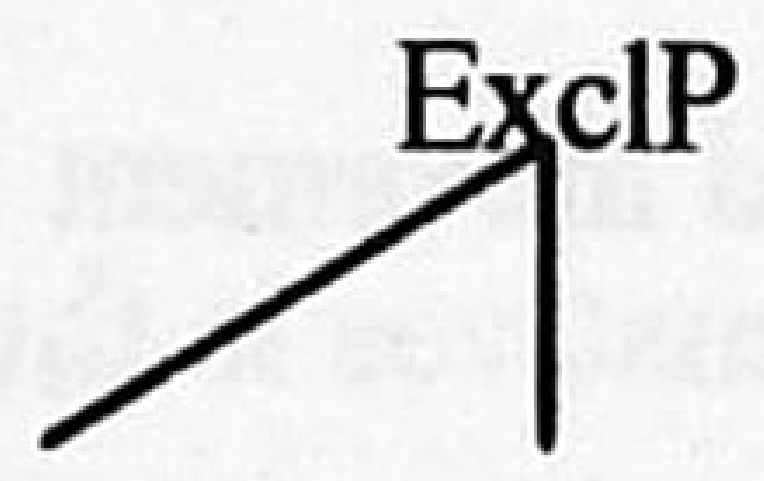

SPEC Excl'
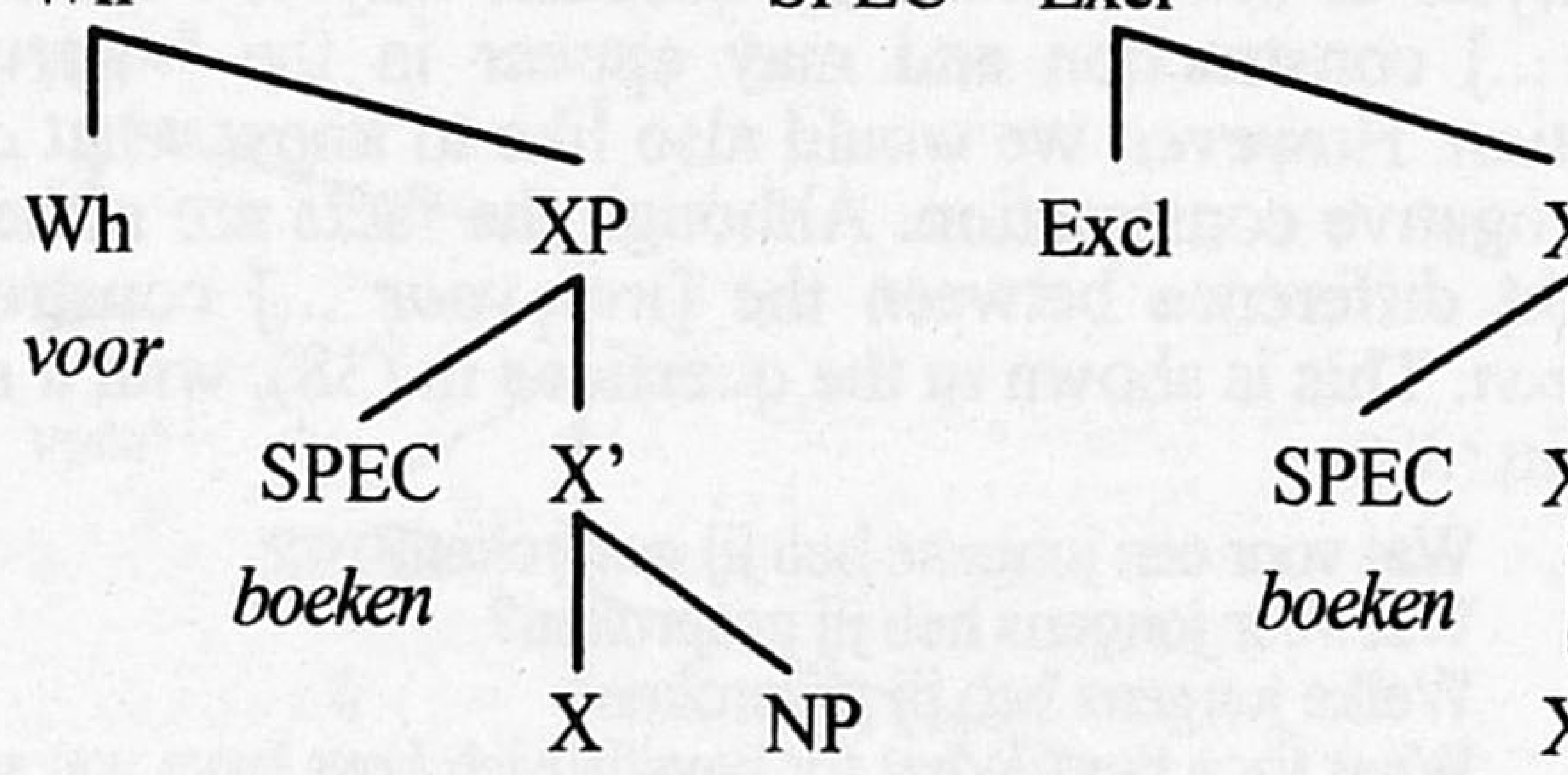

Excl

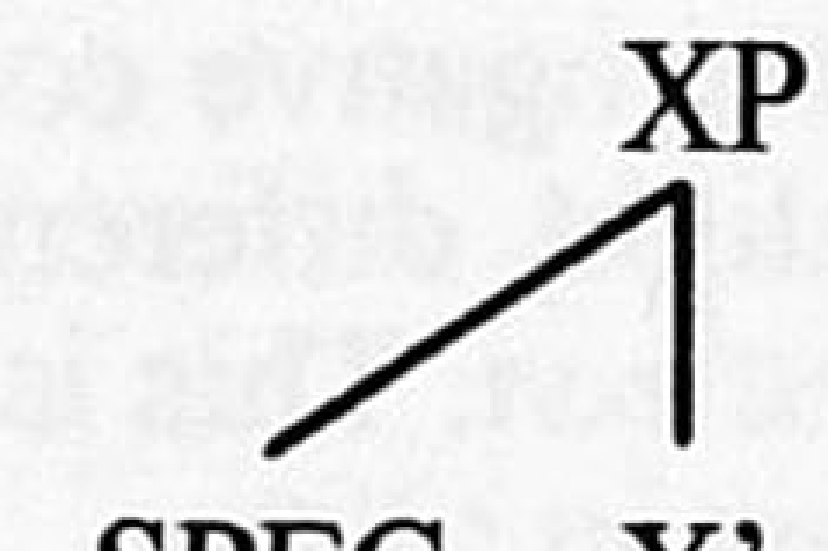

SPEC $X$ '

boeken

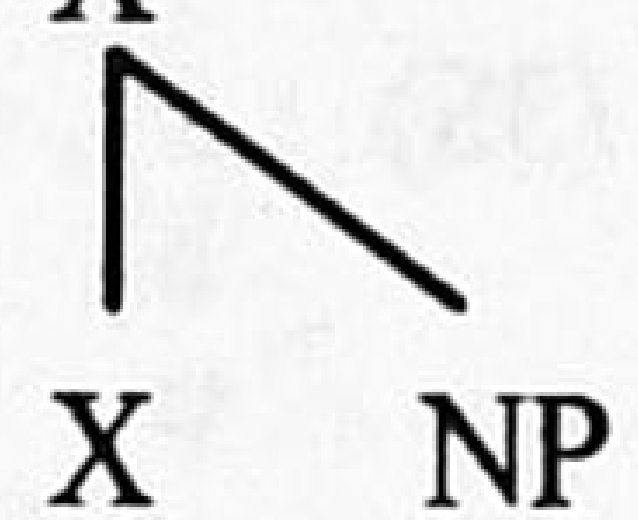

wat

wat

In (36a) voor occupies the head of the WhP, as discussed in the previous paragraph. The NP wat voor boeken is derived through wat-movement to Spec,WhP. One of the central ideas of Bennis, Corver \& Den Dikken (1995) is that een in these constructions originates as the head of the Small Clause (XP in 35-36). The fact that een does not appear to have determiner-like properties is a direct consequence of its structural position. We thus have an answer to the first question: Why does een appear? Featureless een is the lexical manifestation of the head of a nominal Small Clause within DP.

We can now answer the question why een is obligatory in wat-exclamatives as well. We will use a version of Rizzi's (1990) Wh-criterion.

(37) The Wh-criterion

Whenever the specifier position of an operator phrase is filled by an overt constituent, its head must be filled by an overt constituent as well (and vice versa)

If we assume that the quantifier wat in the wat voor (een) and the wat een construction is moved to an operator position (its underlying position being the predicate of a nominal Small Clause), the criterion in (37) requires the head of the operator phrase to be overt. In the preceding paragraph we argued that voor occupies the head of the Wh-operator phrase. Since voor satisfies the requirement of the Wh-criterion, een may optionally be present. If the specifier position of the exclamative phrase is not lexically filled, as in (34), the Wh-criterion does not apply, and een is optionally present again. But if wat is moved to the specifier position of the exclamative phrase in (36b), there is no other candidate than een to fill the head of this phrase in order to satisfy the Wh-criterion. Een is 
moved through head movement from $\mathrm{X}$ to Excl. The obligatory presence of een in wat-exclamatives is thus due to the criterion in (37).

This analysis of een answers the question why een must appear in the [wat een ...] construction and may appear in the [wat voor (een) ...] construction. However, we would also like to know what een is doing in the interrogative construction. Although the facts are rather subtle, there is a slight difference between the [wat voor ...] construction with or without een. This is shown in the questions in (38), with a set of potential answers in (39).

(38) a Wat voor een jongens heb jij gesproken?

b Wat voor jongens heb jij gesproken?

c Welke jongens heb jij gesproken? What for a boys/What for boys/Which boys have you spoken
a Teun, Johan en Harry
b Aardige jongens (nice boys)
(38a) *, (38b) ?, (38c) ok (38a) ok, (38b) ok, (38c) *

According to most informants the difference between (38a) and (38b) is that the answer in (39a) is impossible for (38a), and questionable for (38b). Apparently the presence of een requires the [wat voor ...] phrase to have a non-specific interpretation. In Bennis, Corver \& Den Dikken (1995) it is argued that this interpretive effect is due to Predicate Inversion within the nominal domain. ${ }^{11}$ In the case that een is present, wat, being the predicate of the nominal Small Clause, reaches the operator position after Predicate Inversion.

This leads us to the following structure of the [wat voor een ...] construction: 
(40)

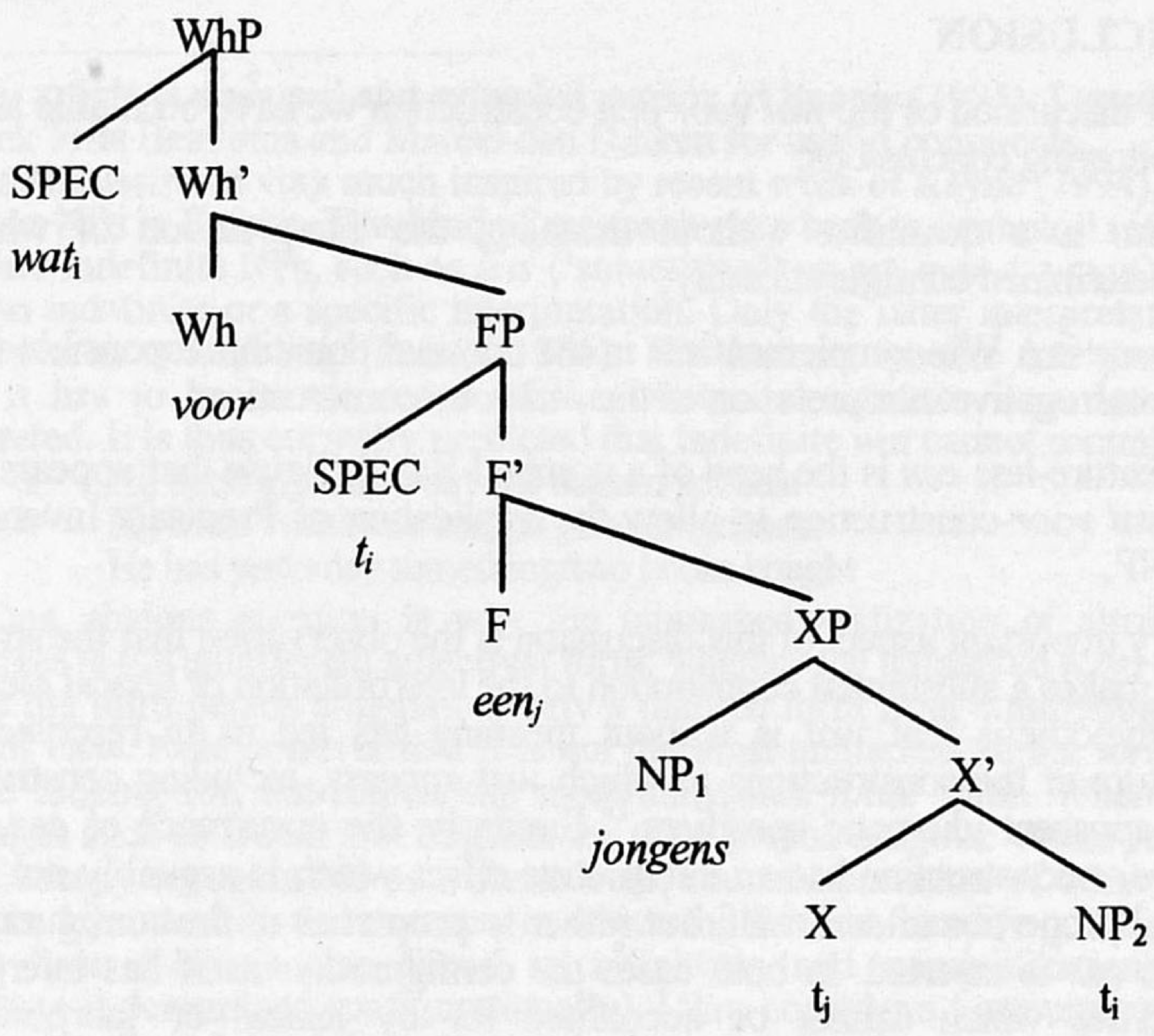

The predicate wat of the nominal Small Clause (XP) is first moved to the specifier of a higher functional projection (FP) as an instance of the Amovement rule of Predicate Inversion. In order to prevent a violation of Equidistance (the central locality constraint in the minimalist framework), the head of XP (een) is moved to $\mathrm{F}$. X-to-F makes $\mathrm{NP}_{1}$ and [Spec,FP] equidistant. Movement of $\mathrm{NP}_{2}$ to [Spec,FP] is an instance of Predicate Inversion and gives rise to an interpretive effect, as is shown in (38) and (39). After Predicate Inversion wat is moved to the specifier of the $\mathrm{WhP}$ in order to satisfy the Wh-criterion in (37).

If een is absent, FP is absent as well, and the structure is like (36a). Een is not necessary, and will not be realized in X. Wat can be moved to [Spec,WhP] in one step, and the interpretive effect of Predicate Inversion is absent. $^{12}$ 


\section{CONCLUSION}

In our discussion of the wat voor een construction we have been able to draw the following conclusions:

- wat is a quantifier without meaning, the interpretation of which is determined configurationally;

- voor is a Wh-complementizer in the nominal domain, responsible for the interrogative interpretation of the wat voor-construction;

- feature-less een is the head of a nominal Small Clause that appears in the wat voor-construction to allow the application of Predicate Inversion in NP.

A very important aspect of this discussion is the observation that the structure itself makes a substantial contribution to the interpretation of lexical elements. The hypothesis that wat is without meaning has led us to reconsider the structure of the constructions in which wat appears, including constructions with apparent idiomatic specifiers. ${ }^{13}$ Similarly, the occurrence of een in the wat voor-construction has an interpretive effect which is arguably not due to lexical properties of een itself, but rather to properties of the configuration in which een is inserted. In both cases the configuration itself has interpretive properties which cannot be accounted for by lexical or morphological features, since wat and een do not have such features. They are grammatical formatives. Their movement is structurally driven, and has interpretive consequences. The analysis presented here thus constitutes a counterexample to the view that both structure and movement are determined by lexical and morphological features, as is the standard assumption in the minimalist program. The question is whether this constitutes a serious threat to the minimalist approach. In my view it does not. If we give up the morphological approach, much of the basic assumptions with respect to the organization of the model and notions such as economy and locality can be maintained. It might even be an enrichment of the model if we assume that both (functional) structure and movement are determined by non-lexical, interpretive properties of the configuration. 
Meaning of structure and the minimalist program

\section{NOTES}

1 This article is a revised and extended version of Bennis (1995). I would like to thank Frits Beukema and Marcel den Dikken for useful comments.

2 This discussion is very much inspired by recent work of Kayne (1994) about complex NPs in French. This kind of approach goes back to Szabolcsi (1983).

3 Other indefinite NPs, such as iets ('something') or een man ('a man') may have an indefinite or a specific interpretation. Only the latter interpretation is allowed after scrambling (Bennis 1986). Wat has no specific interpretation since it has to be in the scope of the existential operator in order to be interpreted. It is thus correctly predicted that indefinite wat cannot scramble:

(i) a Hij heeft gisteren wat/twee boeken gekocht

b Hij heeft * wat/twee boeken gisteren gekocht

He has yesterday something/two books bought

4 One obvious question is why the unmarked realization of attributive adjectives is the uninflected adjectival form, whereas the unmarked form of the verb is the third person singular, clearly a marked form from a morphological point of view. Note however that it is not the most unmarked verbal form that we are looking for, but rather, the most unmarked finite form. Whereas in languages such as Dutch and English the third person singular verbal form is unequivocally recognizable as a finite verb, the interpretation of other finite forms is dependent on the structure in which the form is found (e.g. the plural verbal form (-en) is also found in infinitives and nominalizations; the difference is determined configurationally). I thus consider a form unmarked if it represents the minimal form that can be interpreted without context.

5 A third construction in which wat is found is the [wat ...]-AP construction. There is no interrogative [wat ...]-AP construction, but both exclamative and indefinite $[$ wat ...]-AP are found. These [wat ...]-APs are like [wat ...]-NPs with respect to the fact that the interpretation of the [wat ...]-AP is not configurationally determined. They differ from [wat ...]-NPs in that there is no AP-internal lexical difference between exclamative and indefinite [wat ...]APs. A detailed discussion of sentences such as in (i) lies outside the scope of this paper.
(i) $\mathrm{a}$
Die opgave is wat moeilijk
That task is very/somewhat difficult
b
Wat moeilijk is die opgave
Very/Somewhat difficult is that task
$\left(\right.$ excl/indef $\left.{ }^{*} \mathrm{Wh}\right)$
(excl/indef $\left.{ }^{*} \mathrm{Wh}\right)$

6 In Bennis (1983) it is argued that after wat-extraction the remaining phrase may behave as a PP, in the sense that this phrase appears in a postverbal PPposition, although this phenomenon is somewhat marked. An example is given in (i).

(i) ?Wat heeft Jan gisteren gekocht voor boeken?

What has John yesterday bought for books 
I argued that the PP-status of the voor-phrase was due to reanalysis. This conclusion is reinforced by the fact that a similar kind of reanalysis can be observed in the case of dan and als ('than'/'as'). The comparative complementizer dan/als is reanalyzed as a preposition in substandard sentences such as "Jan is groter dan/als mij" ('John is bigger than/as me'). The occurrence of objective case on the NP after dan/als, instead of the standard nominative, is due to the exceptional prepositional status of dan/als. An additional argument in favour of reanalysis of dan/als is the fact that objective case on the NP becomes clearly ungrammatical if dan/als is followed by more than one phrase, as in "Dick heeft meer CDs dan/als ik/*mij boeken"('Dick has more $\mathrm{CDs}$ than/as I/me books'). Reanalysis requires a PP-compatible structure.

7 Note that a construction which is apparently quite similar to the wat voorconstruction, the wat aan-construction (cf. Corver 1990) appears to allow relativization, as in "alles wat ik aan boeken heb ..." ("everything what I to books have", 'all the books that I have'). This appears to favour Corver's conclusion that wat aan boeken is not a constituent; wat is the single wat discussed in the preceding paragraph.

8 The use of voor as complementizer is quite common in southern Dutch and Flemish (cf. Cornips 1994). It is remarkable that it shows up in infinitival relatives, a context in which there is operator movement to SpecCP.

9 In Bennis, Cover \& Den Dikken (1995) the wat-constructions under investigation are related to other constructions in which featureless een shows up. The most important of these is the well known een schat van een kindconstruction (cf. Paardekooper 1956). This construction is also found in English in cases such as $a$ hell of a problem. For the present discussion the most relevant aspect of this construction is that the element een or $a$ in front of the second noun does not belong to this noun, as is evident from the (somewhat marked) acceptability of schatten van een kinderen ('darlings of a children'). An extensive discussion of this construction is found in Den Dikken (1995).

10 I do not assume that the labels WhP or ExclP have any theoretical value. They are used to indicate that we are concerned with DPs with a head that is interpreted as Wh or Excl.

11 Nominal Predicate Inversion in the verbal domain is found in sentences such as The best candidate is John, derived from John is the best candidate. It is best analyzed as an A-movement rule moving the predicate to subject position (Hoekstra \& Mulder 1990 a.o.). Predicate Inversion in the schat van een kind construction is a major subject in Den Dikken (1995).

12 In this case there is no violation of equidistance since it concerns movement to an operator position.

13 It is clear that this analysis has several aspects in common with existing analyses for related phenomena, such as Wh-in-situ (Pesetsky 1989), Clitic Left Dislocation (Cinque 1990), and French constructions with the element de (Hulk \& Verheugd 1994, Kayne 1994). These subjects will be dealt with in future research. 


\section{REFERENCES}

Bennis, H. (1983) 'A case of restructuring', in H.Bennis \& W.U.S. van Lessen Kloeke (eds.) Linguistics in the Netherlands 1983, Foris, Dordrecht.

Bennis, H. (1986) Gaps and Dummies, Foris, Dordrecht.

Bennis, H. (1995) 'The meaning of structure: the wat voor construction revisited', in M. den Dikken \& K. Hengelveld (eds.) Linguistics in the Netherlands 1995, John Benjamins, Amsterdam.

Bennis, H. \& T. Hoekstra (1984) 'Gaps and Parasitic Gaps', The Linguistic Review 4, 29-87.

Bennis, H., N. Corver \& M. Den Dikken (1995) 'Predicate Inversion in Nominal Phrases', paper presented at the 11th Comparative Germanic Syntax Workshop, Rutgers University, New Brunswick (USA), 3 November 1995.

Besten, H. den (1985) 'The ergative hypothesis and free word order in Dutch and German', in J. Toman (ed.) Studies in German Grammar, Foris, Dordrecht.

Cinque, G. (1990) Types of $A^{\prime}$-Dependencies, MIT-Press, Cambridge (MA).

Chomsky, N. (1993) 'A minimalist program for linguistic theory', in K. Hale \& S.J. Keyser (eds.) The view from Building 20, MIT-Press, Cambridge MA.

Cornips, L. (1994) Syntactische variatie in het Algemeen Nederlands van Heerlen, diss. IFOTT, University of Amsterdam.

Corver, N. (1990) The Syntax of Left Branch Extractions, diss. KUB, Tilburg.

Corver, N. (1991) 'Wat voor constructie is de 'wat voor'-constructie', Spektator 20, 151-185.

Diesing, M. (1988) 'Bare plural subjects and the stage/individual contrast' in M. Krifka (ed.) Genericity in Natural Language, Tübingen.

Dikken, M. den (1995) Copulas, ms. HIL / Vrije Universiteit Amsterdam.

Hoekstra, T. \& R. Mulder (1990) 'Unergatives as copular verbs: locational and existential predication', The Linguistic Review 7, 1-79.

Hulk, A \& E. Verheugd (1994) 'Accord et Opérateurs Nuls dans les Projections Adjectivales', Revue Québécoise de Linguistique 23, 17-45. 
Kayne, R. (1994) The antisymmetry of syntax, MIT-Press, Cambridge MA.

Pesetsky, D. (1989) ' $W h$-in-situ: Movement and Unselective Binding', in E. Reuland \& A. ter Meulen (eds.) The Representation of (In)definiteness, MIT-Press, Cambridge MA.

Postma, G. (1994) 'The indefinite reading of Wh' in R. Bok-Bennema \& C. Cremers (eds.) Linguistics in the Netherlands 1994, John Benjamins, Amsterdam.

Postma, G. (1995) Zero Semantics; A Study of the Syntactic Construction of Quantificational Meaning, diss. HIL Leiden.

Reuland, E. (1983) 'Onderzoek van het Nederlands en het zoeken naar verklaringen', TTT 3.

Rizzi, L. (1990) Relativized Minimality, MIT-Press, Cambridge MA.

Szabolczi, A. (1983) 'The Possessor that ran away from home', The Linguistic Review 3, 89-102. 